\title{
Iz prvotnih ledinskih imen tvorjena hišna imena v spodnji Zadrečki dolini
}

\author{
Peter Weiss (Ljubljana)
}

IZVLEČEK: V Zgornji Savinjski dolini so najstarejša hišna imena tista, ki so tvorjena iz prvotnih ledinskih imen. Prispevek predstavlja današnjo razširjenost tovrstnih hišnih imen v spodnji Zadrečki dolini (kjer se med Gornjim Gradom in Nazarjami govori zgornjesavinjsko narečje) z izpeljankami vred.

ABSTRACT: In the Upper Savinja Valley, the oldest oeconyms were formed from names that were originally microtoponyms. This article presents today's distribution of such oeconyms in the Lower Dreta Valley (where the Upper Savinja dialect is spoken between Gornji Grad and Nazarje), including their derivatives.

0 V Zgornji Savinjski dolini so med najstarejšimi hišnimi imeni tista, ki so tvorjena iz prvotnih ledinskih imen. Prvič so bila strnjeno zapisana leta $1426 \mathrm{v}$ urbarju benediktinskega samostana v Gornjem Gradu (Orožen 1876, 215-322). Raba tovrstnih imen na severozahodu Zgornje Savinjske doline, predvsem v okolici Solčave in tudi v okolici Luč, je bila obravnavana že večkrat (Štiftar 1873; Mišič 1938, predvsem 191-192; Mišič 1940; Vider 1982, 86-90), ${ }^{1}$ za spodnjo Zadrečko dolino, kjer se med Gornjim Gradom in Nazarjami govori zgornjesavinjsko narečje, pa podrobneje še ni bila opisana. Tule je obravnavano isto zemljepisno področje kot v poskusnem zvezku slovarja govorov Zadrečke doline med Gornjim Gradom in Nazarjami (Weiss 1998, 8-9, 6).

1 Razlikovanje hišnih imen, ki so nastala iz prvotnih ledinskih, od hišnih imen, ki so tvorjena iz priimka (»rodbinskega imena«), imena, vzdevka, poklica ipd., tipa Tinček/Tinčki in Kovač/Kovači je mogoče najti pri Francu Mišiču: »Prevladovanje hišnih imen, ki so nastala iz ledinskih, nad hišnimi imeni, ki so osebnega značaja, je razumljivo iz poseljenosti pokrajine; zaledje Luč je izrazito ozemlje

1 Podatke o oblikah hišnih ipd. imen za Solčavo in okolico mi je 18. februarja 1988 poslal gospod Valent Vider iz Solčave, za kar se mu tudi tu lepo zahvaljujem. Primerjava njegovega seznama s stanjem v spodnji Zadrečki dolini kaže, da nekateri tipi tvorbe pridevnikov iz hišnih imen oz. iz imena gospodarja tu niso znani (žibovčji, šúmečji, kleménčji). 
$\hookrightarrow \quad$ samotnih kmetij, kjer stik med ljudmi ni tako živ kakor v sklenjenih vaseh, zato je tu pri poimenovanju prihajala $v$ večji meri do izraza označitev lege ali položaja kmetskega dvorca ko karakteristika njegovega prebivalca.« (Mišič 1940, 49) In še: »Iz objavljenega gradiva vidimo, da so ledinska in njim odgovarjajoča hišna imena v okolici Luč zelo stara in da so se v večini primerov skozi stoletja ohranila prav do danes. Hišno ime, nastalo iz imena ledine, na kateri hiša stoji, je izraz povezanosti naselnika z ledino in zemljo, ki jo obdeluje, in je zato stalno in skoraj neizpremenljivo [..] Krije se hišno ime z rodbinskim tam, kjer je dom ostal nepretrgano v lasti prvotnega rodu. To, kar pa je tudi pri izpremembah v lastništvu ostalo in ostaja neizpremenjeno, je hišno ime.« (Mišič 1940, 49)

2.1 Zemljevidi (npr. Gornji Grad 075; Mozirje 076; AS 1996) in imeniki (npr. Blaznik 1986) za obravnavano področje namesto teh, prvotno ledinskih in danes (tudi) hišnih imen, ki so danes množinska, večinoma navajajo kot hišna imena shematične edninske oblike, kakršne najdemo marsikje na podeželju na siceršnjem slovenskem jezikovnem ozemlju, kar pa je za spodnjo Zadrečko dolino neustrezno, saj tu pomeni ime gospodarja v konkretni hiši. ${ }^{2}$

$2.2 \mathrm{Na}$ zemljevidih in $\mathrm{v}$ imenikih so na obravnavanem področju namesto dejanskih hišnih imen rabljena poknjižena edninska poimenovanja za gospodarja praviloma tudi tam, kjer je današnje hišno ime nastalo iz prvotnega ledinskega imena, ki se še vedno uporablja za posestvo in kot hišno ime. V tukajšnjem gradivu je ta, pisarniška raba dokumentirana z državno topografsko karto (Gornji Grad 075; Mozirje 076).

3.1 Večinsko rabljena hišna imena na obravnavanem področju spodnje Zadrečke doline so tipa Tínčki in Kováči in izkazujejo tákole besedno družino:

(a) hišno ime, ki je (samo)množinska oblika imena gospodarja (tako da so ta imena vedno moškega spola ${ }^{3}$ ); pri tovrstnih imenih so v rabi predlogi pri (na vprašanje $k j e$ ), $k / h$ (na vprašanje $k a m$ ) in od (na vprašanje od kod);

(b) ime gospodarja;

(c) ime gospodarice in/ali gospodinje;

(č) pridevnik iz hišnega imena na $-O V-a-o$ ipd.

3.1.1 Hišna imena, ki niso nastala iz ledinskih imen, so (samo)množinska (npr. "ma'rinšake -u m mn. Marínščaki Marínšeki|Bočna| [Gornji Grad 075, Marinšek]). Edninska oblika, ki je na velikem delu slovenskega ozemlja hkrati tudi hišno ime, ${ }^{4}$ se uporablja za gospodarja ("ma'rinšak -a m mn. Marínščak Marín-

2 Na kartah Gornji Grad 075 in Mozirje 076 državne topografske karte v merilu 1 : 25.000 so zapisana hišna imena, ki jih v taki obliki večinoma navaja tudi AS $1996 \mathrm{v}$ več izdajah v merilu $1: 50.000$, vendar pa jih je v atlasu manj; v njem npr. manjka ime vzpetine Juški vrh.

3 Prim. npr. pri Jerici, pri Marini, pri Pavli (Škofic 2001, 24, 26).

4 »hišno imé - osebno ime, s katerim se navadno v kmečkem okolju poimenuje hiša, domačija, ne glede na priimek, ime ali vzdevek trenutnega gospodarja (Keber 2002a, 143). Prim. še Keber 2002, 61, kjer je ob nejasnostih o edninskih oz. množinskih oblikah hišnih imen treba poudariti sklepno Kebrovo ugotovitev pri hišnih imenih: »Glede na po- 
šek), za gospodarico in/ali gospodinjo pa izpeljanka iz tega imena ("ma'rinšca -e ž Marínščica). Pridevnik iz imena gospodarja (v konkretnem primeru "ma'rinšakọ -ava -ə prid. Marínščakov Marínšekov) se nanaša tako na konkretnega gospodarja kot na hišo oz. družino, s tem da je natančno pomensko razlikovanje med enim in drugim včasih težavno, če je sploh potrebno. Če je že treba razlikovati, se uporabi konstrukcija od + rod. (v ednini za gospodarja in v množini za hišo oz. družino), kar je sploh navadno, če je priložnostna razlikovalna sestavina hišnega imena ali imena gospodarja pridevnik, največkrat Spodnji ali Zgornji pred ustreznim imenom ali pridevnik iz naselijskega imena, ki natančneje določa hišo ali gospodarja, ki sta imenovana enako v različnih vaseh: razlikovanje pri hišnem imenu na način kráški (< spodnjekraški< Spodnje Kraše) :: šmárčki Hrástniki (ali Hrástniki iz Kráš :: iz Šmártna ali $v$ Krášah :: $v$ Šmártnu) je redko, ker ga večinoma določa sobesedilo, pogostejše pa je pri gospodarju na način kráški :: šmárčki Hrástnik (ali vzporedno Hrástnik iz Kráš :: iz Šmártna ali $v$ Krášah :: v Šmártnu), ker so gospodarji pač mobilnejši. (K pridevniku iz hišnega imena v zvezah Kovačeva teta (Micka) ali Vrtački stric Franc prim. Weiss 2003, 210-211.)

3.1.2 Posebnost je narečna končnica -e (oz. -ə) pri tovrstnih hišnih imenih v mestniku množine, ko se odgovarja na vprašanje kje. Npr. pər "ma'rinšake pri Marínščakih je za hišno ime navadno in običajno, vendar pa izjemno v primerjavi z občnoimenskimi predložnimi zvezami pər 'bikex, pər 'mo:žax, pər 'kư⿱o:nex (prim. Weiss 1998, 33-34, predvsem opombe m1/7, m2/4 in m3/3). Končnica -e (nam. -ex) oz. -ə (nam. -ax), če se osnova končuje na za č š ž ̌̌ r j, je iz mestnika ednine (Ramovš 1952, 41, 49), tako kot v starinski stalni zvezi pə s'vẹ:tẹ nam. navadnega pə s'vie:tə 'po svetu' ali v prislovu na 'varrxę 'zgoraj'. Vendar pa je končnica -e (oz. -ə) pri hišnih imenih možna le, če samostalnik na levi nima pridevnika; če ga ima, je tudi pri hišnih imenih navadna končnica -ex oz. -ax, torej pər 'bỏ:čkęx "kə'vå:čax (pri Kovačih v Bočni - prim. točko 2.1.1), pər z'gỏ:rnẹx "pə'tọ:čnękex (priložnostno, v pomenu $v$ Zgornjem Potoku (v Rovtu pod Menino)) ali pər 'tətęx "'tinčke 'dẹ: pri teh Tinčkih (tj. pri družini, ki živi v hiši Tinčkovih) zdaj. Ta končnica se kdaj sliši tudi v mestniku (nat "kə'vårčə nad Kovači namesto sploh v siceršnjih, torej nehišnoimenskih besedah navadne končnice -əm, npr. nat "kə'vå:čəm, v Bočni pa ob tem tudi nat "kə'vå:čax), vendar pa gre tu za vpliv knjižnega jezika.

3.2 Na obravnavanem področju najstarejši govorci dobro razlikujejo bližnji rabi podobnih poimenovanj, in sicer ime gospodarja kake hiše in ime katerega koli drugega moškega v tej hiši, pa tudi ime gospodarice in/ali gospodinje in ime katere koli druge ženske v konkretni hiši.

Pri poimenovanjih moških po hišnem imenu je "ble'kå:č -a (in povsod tudi "blẹ-) m Blekáč|Spodnje Kraše| gospodar, "ble'kå:čọ -ga m oz. prid., ed. m. sp. Blekáčev pa splošno poimenovanje za katerega koli drugega moškega v tej hiši, s stališča mlajših z dodatkom st'rịc (kar lahko glede na okoliščine pomeni tudi gospodarja, konkretizira pa se lahko še z dodanim razlikovalnim rojstnim imenom na način "vər'tå:čke st'rịc "f'rənc Vrtački stric Franc ali "vər'tå:čke st'rịc "rud'l Vrtački stric

vedano je kljub dobri raziskanosti posameznih predelov za zdaj težko podati kakšne celovite izsledke o hišnih imenih na slovenskem etničnem ozemlju.« 
- Rudelj) ali "ble'kårčọ 'pó:p Blekačev fant ali "ble'kå:čọ "tỏ:na Blekačev Tona ipd. (Na ta način se glede na okoliščine s stališča starejših od njega ali s stališča njegovih vrstnikov lahko imenuje gospodar ali pa kateri koli od Blekačevih moških.)

Pri poimenovanjih žensk po hišnem imenu je npr. "bleka'çica -'čice (in povsod tudi blẹ-) ž Blekačíca (< Blekáć) gospodarica in/ali gospodinja, medtem ko je "ble'kå:čova -e ž, rod. mn./dv. -ęx poimenovanje za snaho ali za katero koli drugo žensko iz hiše Blekačevih, ki ni gospodarica in/ali gospodinja (kar pa z dodatkom 'tieita ali $\mathrm{z}$ dodanim rojstnim imenom ponazori odnos govorečega do $\mathrm{v}$ konkretnem primeru gospodarice in/ali gospodinje). Mlajši govorci imena gospodarjev in gospodaric in/ali gospodinj čedalje pogosteje zamenjujejo z drugim tipom (npr. "ble'kå:čọ (st'rịc ali "tỏsna) Blekačev stric ali Tona ali "ble'kå:čova ('tie:ta ali "brị'gịta, star. "bri'gịta) Blekačeva teta ali Brigita).

4 Praviloma je besedna družina hišnega imena iz prvotnega ledinskega imena na obravnavanem področju takale: ${ }^{5}$

(a) prvotno ledinsko ime (večjega ali manjšega zemljepisnega področja), ki se je preneslo na hišo, dom, in je s tem vzpostavilo hišno ime; ime tako identificira dvoje, pri čemer ni mogoče vedno natančno določiti, na kaj točno se nanaša: Bil sem na Vrtačah |Spodnje Kraše| pri stricu Francu se z veliko gotovostjo na hišo, Sankali smo se na Vrtačah pa na ledinsko (ali terensko) ime (ali mikrotoponim) oz. - širše - na posestvo v lasti Vrtačkih; predlog, ki je v rabi za tovrstno ime, je na (:: $z / S)$ ali $v(:: i z$ - ta $v$ narečju oblikovno sovpade s predlogom $z / s)$, ne pri itd., kot pri imenih tipa Kovači;

(b) ime gospodarja;

(c) ime gospodarice in/ali gospodinje;

(č) pridevnik iz hišnega imena na $-s k i-a-o,-s ̌ k i-a-o,-c ̌ k i-a-o{ }^{6}$

4.1 V skupini prvotnih ledinskih imen so vsa imena, ki izkazujejo katero od naštetih značilnosti ledinskih imen, saj je brez novih virov nemogoče ugotoviti, ali so ta imena kako značilnost izgubila ali pa je nikoli niso imela (npr. ob izkazanem ledinskem imenu v vlogi hišnega imena pridevniške oblike na -ski, ki jo je morda nadomestila oblika na -oV - prim. točko $\mathbf{5 . 3}$ - ali ob izkazani pridevniški obliki na -ski neobstoj ledinskega imena - prim. točko 5.2).

5 Vpliv preostalih, mlajših hišnih in večinskih imen tipa Kováči je pri nekaterih imenih in pri pridevnikih $\mathrm{k}$ njim povzročil posamezne posebne razvoje, te posebnosti pa je smiselno dokumentirati. Izjeme pri tem vzorcu ne prizadevajo imen gospodarja in gospodarice in/ali gospodinje in so treh vrst.

5 Natančnejši podatki za Solčavo in okolico izpričujejo še kak tip hišnih imen, in sicer samostalnik na -ovo, tvorjen iz imena gospodarja: Matkovo, na Matkovem < Matk, Kolarjevo, na Kolarjevem < Kolar, pa tudi Klemenče, na Klemenčem, prid. klemenč (h Klemenšek), Šúmeče, na Šumečem, prid. šumeč < Šumet in Žibovče, na Žibovčem, prid. žibovč < Žibovt. Te podatke mi je pisno posredoval gospod Valent Vider iz Solčave.

6 O pisanju tovrstnih pridevnikov z veliko začetnico (kot v primerih Janez Bleiweis pl. Trsteniški in Ivan Klodič vitez Sabladolski) glede na malo pri drugih podobnih (slovenski, ljubljanski ...) prim. Weiss 2004, 151. 
5.1 Na obravnavanem področju je večina hišnih imen sicer v množinski obliki, in to iz imena gospodarja (Skónčnjaki Skónčneki iz Skónčnjak Skónčnekv Bočni, Tínčki iz Tínček v Spodnjih Krašah).7 Ta vzorec je mogoče ugotavljati tudi v posameznih primerih, ko se poleg hišnega imena iz prvotnega ledinskega imena govori hišno ime, ki je množinska oblika imena gospodarja (Pódgorje in Pódrščaki Pódršeki, Góvek in Góveki, Pródi in Pródniki, Srnják in Srnjákerji). Pri hišnih imenihGóvek in Góveki ter Srnják in Srnjákerji je pridevnik na -ov ipd., pri drugih parnih pa na -ski ipd.

5.2 V nekaterih primerih, kjer v besedotvornem nizu k hišnemu imenu nastopa pridevniška oblika na -ski ipd., ne na -ovipd., je sámo hišno ime množinska oblika imena gospodarja (Skónčnjaki - Skónčki, Zijávčnjaki - Zijávčki, Jugôvniki - Jugôvski). Redko (pri mlajših govorcih čedalje pogosteje) se da slišati priložnostne oblike svojilnih pridevnikov na -ovipd. iz teh hišnih imen, torej Skónčnjakov, Zijávčnjakov, Jugôvnikov.

5.3 Pri hišnih imenih iz prvotnih ledinskih imen je pridevniška oblika na -ski ipd. sicer večinska (Bákovica - bákovski), vendar pa so pri nekaterih hišnih imenih iz prvotnih ledinskih imen v rabi samo pridevniki na -ov (Hósta - Hóstnikov, Láze - Láznikov, Slopí-Slopníkov; Sprebíja in Sprebítniki-Sprebítnikov in Sprebítkov, Srnják in Srnjákerji-Srnjákerjev, Góvek in Góveki-Góvekov).

5.4 Prvotno ledinski in tudi hišni imeni Péšanik in Góvek se oblikovno ujemata $\mathrm{z}$ imenom gospodarja, s tem da ima ime gospodarja podspol živosti, ki ga hišno (in ledinsko) ime seveda nima. Pridevnik iz ledinskega in hišnega imena Péšanik je na -ski, iz enako glasečega se imena gospodarja pa seveda na -ov, medtem ko je pridevnik iz obeh imen Góvek na -ov.

6.1 Predvsem mlajši narečni govorci so pri nekaterih besednih oblikah negotovi, saj imena gospodarjev in gospodaric in/ali gospodinj govorijo redko, jih pa od starejših lahko vendarle še pogosto slišijo. Za starejše se jim namreč ne spodobi uporabljati imen Kováč in Kovačíca in namesto njih govorijo na način Kóčnikov stríc, Kóčnikov stríc Frànc (na način Kóčnikov Frànc govorijo o konkretnem posamezniku vrstniki ali starejši od njega), Kováčeva têta, Kováčeva têta Mícka (kjer spet na način Kováčeva Mícka govorijo o konkretni posameznici vrstniki ali starejši od nje). Namesto hišnih imen iz prvotnih ledinskih imen je predvsem pri mlajših čedalje pogosteje slišati množinske oblike imena gospodarja (na način pri Vrtáčniki) ali v vlogi hišnih imen kar ime gospodarja (na način pri Vrtáčniku).

Hišna imena iz prvotnih ledinskih imen so torej le omejeno tvorna ( $\mathrm{Vi}$ clôvec $\rightarrow$ Viclôvnik), medtem ko hišna imena iz imena gospodarja so, v Spodnjih Krašah npr. Zvíri $\leftarrow$ Zvír ali Zvírnjaki $\leftarrow$ Zvírnjak, Drágoti iz rojstnega imena Drágo, Gréhčev Tóna $\leftarrow$ Gréhci in predvsem pri mlajših govorcih v zadnjem času

7 Janez Trdina je leta 1870 to vrsto imena, kot je bilo v rabi na Dolenjskem, imenoval družinsko ime. »Rabijo se tod [namreč v Bršljinu pri Novem mestu, kjer je Trdina živel leta 1870 - Trdina 1987, *12] vedno še družinske imena, na pr.[imer] grem k Malnarjevim, ne: k Malnarju, pri Kovačevih, Ljubčevih, Jelenčevih etc.« (Trdina 1987, 16). 
Vrtáčniki $\leftarrow$ Vrtáče. ${ }^{8}$ Od tod do pridevnika Vrtáčnikov iz hišnega imena Vrtáčnikov nam. Vrtáčki ni več daleč. ${ }^{9}$

6.2 Nekatera hišna imena obstajajo le še v spominu informatorjev, saj so hiše, na katere so se nanašala, izginile in so lahko z gozdom zaraščena tudi že cela posestva, npr. v Nadbočni, zaselku Bočne na severnem pobočju Menine. Tu k hišnima imenoma Petríja || "pẹt'rija -a ž $\rangle$ u "pẹt'rijo in Žvotíja Žvatíja || "žva'tija -a ž \langle\rangle u "žva'tijə ni mogoče več slišati drugih oblik (imen gospodarja in gospodarice in/ali gospodinje ter pridevnika $\mathrm{k}$ hišnemu imenu).

7.1 Hišna imena iz prvotnih ledinskih imen - tule jih je 43 (osnove soodnosnih imen s pridevnikoma Spodnji in Zgornji so štete po enkrat) - so iz 12 vasi (od $14 \mathrm{z}$ obravnavanega področja):

Bočna (9): Bákovica, Hósta, Hríber, Krvíja, Lipíca, Mataróžniki, Pogledíja, Skónčnjaki, Zakót (Petríja in Žvotíja - gl. točko 6.2)

Čreta pri Kokarjah (3): Javórje, Jugôvec, Závršniki

Dobletina (1): Gomírje

Kokarje (3): Góvek, Zijálka, Žífrje

Lačja vas (4): Péšanik, Séče, Šetínec, Viníše

Potok (3): Pródi, Srnják, Tráte

Pusto Polje (2): Kozólčnjaki, Plónova

Rovt pod Menino (13): Drága, Gnilôvec, Járše, Kŕnčnjaki, Láze, Léskelica, Pistôta, Pôtok, Slopí, Temník, Viclôvec, Vóloga, Vrtáčniki

Spodnje Kraše (1): Vrtáče

Šmartno ob Dreti (1): Sprebíja

Volog (2): Litóžič, Pódgorje

Zavodice (1): Júšje

7.2 Sestavine gesla v tu dodanem seznamu so: (1) hišno ime s podatkom o naselju, v katero spada hiša, na katero se nanaša ime, za \langle\rangle pa stoji mestniška oblika, ki odgovarja na vprašanje kje?, (2) ime gospodarja, (3) ime gospodarice in/ali gospodinje, (4) pridevnik. Povsod so dodani potrebni slovnični podatki (spol pri samostalnikih, samomnožinskost, kjer oblika ni samoedninska, pridevnik) in uveljavljeni stranski sklonski podatki (pri hišnih imenih za \langle\rangle še mestniška oblika). - V navadnih oklepajih so za označevalnikom in ali tudi navedene glasovne različice, v oglatih oklepajih pa je izpričana oblika imena na državni topografski karti iz leta 1998 (Gornji Grad 075, Mozirje 076). Ponekod je v okroglem oklepaju navede-

8 Malce nenavadno razlaga razvoj tovrstnih imen Janez Mrdavšič: »Pri domačih imenih, kjer je prišlo do nastanka novih domačijskih imen, so ta zapisana pod b« (Mrdavšič 2001, 22). V primeru »a) Knéz [..] b) Knéže, na Knéžem, Knéži« (Mrdavšič 2001, 48) je tako, v primeru »a) Gradišnik [..] b) Gradišse, na Gradíšu, gradišk'« (Mrdavšič 2001, 37) pa najbrž ne.

9 Podobno ugotavlja Mrdavšič 1988, 82: »Najevska lipa [..] pripada najevski domačiji, ne gospodarju, ki ni nujno, da se tudi piše Najevnik, je zato Najevska in ne Najevnikova, kakor jo zadnje čase imenujejo.« 
na še onaglašena oblika priimka, ki domnevno izvira iz imena gospodarja. Zapis priimka ni narečen, ker se v narečju priimki uresničujejo v polcitatni obliki.

7.2.1 Poknjižene oblike imajo včasih navedene različice, s tem da kdaj na prvem mestu stojijo bolj upravičene, vendar presenetljive (Plónovščak Plónovšek) včasih pa so nenavadne in nepričakovane tule edine oblike glede na priimke (Vinišnjak v primerjavi s priimkom in na zemljevidih zapisano obliko hišnega imena Venišnik - prim. Bajec 1950, 82-83). ${ }^{10}$ - K veliki začetnici pridevnika na -ski ipd. (Hudabivška Meta :: karniški Ožbej pri Prežihovem Vorancu) prim. Weiss 2004, 151.

Bákovica (Bočna) ||"båxkọca -e ž〈〉u "bå:kọcę

Bákovnik ||"bå:kọnęk -a (in -nị-) m živ. [Gornji Grad 075, Bakovnik]

Bákovnica ||"bårkọnca -e ž

Bákovski ||"'bå:kọs'ke -a -ə prid.

Dráge (Rovt pod Menino) || "d'rå:ge "d'rå:k ž mn. 〈〉u "d'rå:gex

Drážnik \|" d'rå:žnȩk -a (in -nị-) m živ.

Drážnica || "d'rå:žənca -e ž

Dráški \|| "d'råsške -a -ə prid.

Gnilôvec (Rovt pod Menino) || "gnę'łọ:c -a (in gnị-) m \langle\rangle u "gnę'łọ:cə (in gnị-) [Mozirje 076, Gnovec]

Gnilôvčan in Gnilôvčnjak Gnilôvčnek || "gnę'łọ:čan -a (in gnị-) in "gnę'łọ:čnek -a (in gnị-) $m$ živ.

Gnilôvčanka in Gnilôvčnica \|" "gnẹ'łọ̣čayka -e (in gnị-) in "gnẹ'łọ̣čənca -e (in gnị-) ž

Gnilôvčki || "gnę'łọ:čkę -a -ə prid.

Gomírje (Dobletina) \|" "ga'mèrrjə -a s \langle\rangle u "ga'mėirjə

Gomírščak Gomíršek || "gə’mė:ršak -a m živ.

Gomírščica || "ga'mèrršca -e ž

Gomírski || "gə'mè:rs'ke -ska -ə prid. 〈〉"gə่mė:rs'kẹ k'łårnc (klanec na cesti Nazarje-Gornji Grad v Dobletini)

Góvek (Kokarje) || "gó:vek -a (in -vẹ-) m 〈〉u "gó:vekə (in -vẹ-) [Mozirje 076: Govek] (tudi zgradba kmetijske zadruge)

in Góveki ||"'göıvẹkę -vekọ m mn. 〈〉pər "górvẹkę

Góvek ||"'gó:vek -a (in -vẹ-) m živ.

Góveščica ||"gó:vẹšca -e ž

Góvekov \|" gó:vekọ -va -ə (in -vẹ-) prid.

Hósta (Bočna) || "xọ:sta -s’te ž \langle\rangle u "xọ:s'tę

Hóstnik || 'xọ:s't’nęk -a (in -s’n-; in -nị-) m živ. [Gornji Grad 075, Hrastnik(?)]

Hóstnica \|" "xọrstñca -e (in -sən-) ž

Hóstnikov || 'xọ:s't'nękọ -ava -ə (in -s'n-; in -nị-) prid.

Hríber (Bočna) || "x'rịbər -bra m 〈〉 na "x'rịbrə

10 »Pomen je dan že v pridevnikih na -ski: splošna, ne osebna posest. Besede so v rabi zlasti na vzhodu, v centralnih narečjih se je po glasovnih zakonih -ščak reduciral v-šček, -šč zk in -šsk, tako da danes v njem občutimo obrazilo - $ə k$, zlasti pogosto v rodovinskih imenih: Zakrajšek, Savinšek, Jevšek itd.« (Bajec 1950, 82-83) 
Hríbrnjak Hríbrnek || "x'rịbərnek -a m živ. [Gornji Grad 075, Hribernik]

Hríbrnica || "x'rịbrənca -e ž

Hríbrski || "x'rịbərs'kę -ska -ə prid.

Járše (Rovt pod Menino) ||"jå:rša "jå:rš ž mn. 〈〉u "'jå:ršax

Járšnik ||"jå:ršnęk -a (in -nị-) m živ. [Gornji Grad 075, Jaršnik]

Járšnica ||"jå:ršənca ž

Járški ||"jå:rškę -a -ə prid.

Javórje (Čreta pri Kokarjah) || "ja'vó:rjə (tudi -a) -a s \langle\rangle na "ja'vó:rjə

Javórščak Javóršek \|" ja'vó:ršak -a m živ.

Javórščica \|" ja'vỏiršca -e ž

Javórski || "ja'vỏsrs'kę -ska -ə prid.

Jugôvec (Čreta pri Kokarjah) || "jə'gọ:c -a m \langle\rangle u "jə'gọ:cə

in Jugôvniki || "jə'gọ:ykẹ -ọ m mn. 〈〉 pər "jə'gọ:yke

Jugôvnik ||"ja'gọ:nęk -nka m živ. [Mozirje 076: Jegovnik]

Jugôvnica || "jə'gọ:nca -e ž

Jugôvski || "ja'gọ:s'kę -ska -ə prid.

in Jugôvnikov \|" jə'gọ:ykọ -va -ə prid.

Júšje (Zavodice) ||"jušjə (tudi -a) -a s \langle\rangle na "jušjə

in Júšniki ||"jušnękę (in -ni-) -ọ (in -nị-) m mn. 〈〉 pər"'jušnękę (in -ni-)

Júšnik ||"jušnȩk -a (in -nị-) m živ. [Mozirje 076, Jušnik]

Júšnica \|"jušənca -e ž

Júški ||"juškę -a -ə prid. [Mozirje 076, Juški vrh (517 m)]

Kozôlčnjaki Kozôlčneki (Pusto Polje) || "kə’zọ:čnẹkẹ -ọ (in -nẹ-) m mn. 〈〉 pər "kə'zọ:čnẹkę

Kozôlčnjak Kozôlčnek || "ka'zọ:čnek -a m živ.

Kozôlčnica ||"kə'zọ:čənca -e ž

Kozôlčki || "kə'zọ:čkę -a -ə prid.

Kŕnčnjaki Kŕnčneki (Rovt pod Menino) ||"ka:rənčnẹkę -nekọ (in -nẹ-) m mn. 〈〉pər "ka:rənčnẹke

Kŕnčnjak Kŕnčnek ||'ka:rənčnek -a (in -nẹ-) m [Mozirje 076, Krnčnik]

Kŕnčnica ||"ka:rənčənca -e ž

Kŕnčki ||"'ka:rənčkę -a -ə prid.

Krvíja (Bočna) || "kər'vija -a ž 〈〉 u "kər'vijə"

Krvénik || "kər'vẹ:nęk -'ve:yka (in -'vẹ:-) m živ. [Gornji Grad 075, Krvavnik]

Krvénica || "kər've:nca (in -'vẹ:-) -'vẹ:n'ce ž

Krvêjski || "kər'vẹ:s'kę -'vesska -ə (in -'vẹ:-) prid. [Gornji Grad 075, Krevejske peči]

Láze (Rovt pod Menino) \|" "łå:ze "łå:s ž mn. 〈〉 u "łå:zex

in Lázniki \|" ‘å:z’nękę (in -ni-) -ọ (in -nị-) m mn.

Láznik || 'łå:z’nęk -a (in -nị-) m živ. [Mozirje 076, Laznik]

Láznica \|"'łå:znoca -e ž

Láznikov ||"łå:z’nękọ -va -ə prid.

${ }^{11}$ V govorih spodnje Zadrečke doline ẹ pred j alternira z i, zato "kər'vẹıs'kę in "kər'vija (in tako še 'vẹ:ja in 'vija 'veja', 'rẹ:ja in 'rija 'reja', b'rẹ:ja in b'rija 'breja', u'dẹija in u'dija 'odeja' itd. (Weiss 2001, 329). 
Léskelica (Rovt pod Menino) || "lẹss'kẹlca -e ž \langle\rangle u "lẹss'kẹlcę

Léskovnik ||"lerskọnęk -a (in "lẹ:-; in -nị-) m živ.

Léskovnica ||"'lesskọnca -e (in "lẹi-) ž

Léskovški \||"lerskọškę -a -ə (in "'lẹ:-) prid.

Lipíca (Bočna) || "lę́pịca -'pice ž 〈〉 na "lę̣pịcę

Lipíčnik || "lę'pičnȩk -a (in -nị-) m živ.

Lipíčnica \|" "lę'pičənca -e ž

Lipíčki ||"lę pičke -a -ə prid.

Litóžičč ${ }^{2} \sim$ Litóšč (Volog) || "lẹt'tỏ:šč -a m \langle\rangle u "lệtỏ:ščə (tudi vodno ime)

Litóžnik || "lę'tó:žnȩk -a (in -nị-) m živ. [Gornji Grad 075, Letožnik]

Litóžnica \|" "lę'tó:žənca -e ž (tudi vodno ime)

Litóški || "lę'tȯ:ške -a -ə prid.

Mataróžniki (Bočna) || "mata'rọ:žnękę (in -ni-) -u (in -nị-) m mn. 〈〉 pər "mata'rọ:žnẹkẹ (in -ni-)

Mataróžnik || "mata'rọ:žnęk -a (in -nị-) m živ.

Mataróžnica || "mata'rọ:žənca -e ž

Mataróški || "mata'rọ:ške -a -ə prid.

Péšanik (Lačja vas) || "pẹišanęk -nka m \langle\rangle u "pẹišajkə

Péšanik || "pẹišanęk -nka m živ.

Péšanica ||"pẹ:šanca -e ž

Péšanski ||" "pẹıšans’kę -ska -ə prid.

Pistôta (Rovt pod Menino) \|| "pęs'tuorta -e ž $\langle>$ na "pęs'tuortę

Pistótnik || "pess'tó:t'nȩk -a (in -nị-) m živ. [Mozirje 076, Pestotnik]

Pistótnica || "pęs'tỏ:tnoca -e ž

Pistóčki || "pess'tócčkę -a -ə prid. [Mozirje 076: Pestoški vrh (614 m)]

Plónova (Pusto Polje) || "p'łọ:nọva -e ž 〈 u "p'łọ:nọvę

Plónovščak Plónovšek || "p'łọ:nọšak -a m živ. (priimek Plánovšek)

Plónovščica || "p'łọ:nọšca -e ž

Plónovski || "p'łọ:nọs'kę -ska -ə prid.

Pódgorje (Volog) ||"pó:dgərjə -a s \langle\rangle star. u "pó:dgərjə

in Pódrščaki Pódršeki || "pó:dəršakę -ọ/-u m mn. 〈〉 pər "pó:dəršakę

Pódrščak Pódršek || "pó:dəršak -a m živ. [Mozirje 076, Podgoršek]

Pódrščica ||"pó:dəršca -a ž

Pódrski \||"pó:dərs'kę -ska -ə prid.

Pogledíja (Bočna) || "pəglệ'dija -a ž \langle\rangle na "pəglệdijə

in Poglédniki \|| "pəg'lè:d'nękę -u (in -ni-) m mn. 〈〉 nov., redk. pər "pəg'lè:d'nękę

Poglédnik || "pəg'lè:d'nęk -a (in -nị-) m živ. [Gornji Grad 075, Poglednik]

Poglédnica || "pəg'lèidñca -e ž

Poglédski || "pəg'lèic'ke -cka -ə prid.

Pôtok (Rovt pod Menino) || "punortək "pə'tỏika (nov. "pə'tọ:ka) m〈〉u ("s'pó:d’nęmə, "z'gó:rnęmə) "pə'tỏ:kə (nov. "pə'tọ:kə)

${ }^{12} \mathrm{Za}$ ustno opozorilo na to obliko se zahvaljujem kolegu Silvu Torkarju.

${ }^{13}$ Pôtok je tudi ime naselja v občini Nazarje, ki ima v stranskih sklonih druge oblike: "puno:tək "pə'tọ:ka m 〈〉 u "pə'tọ:kə. 


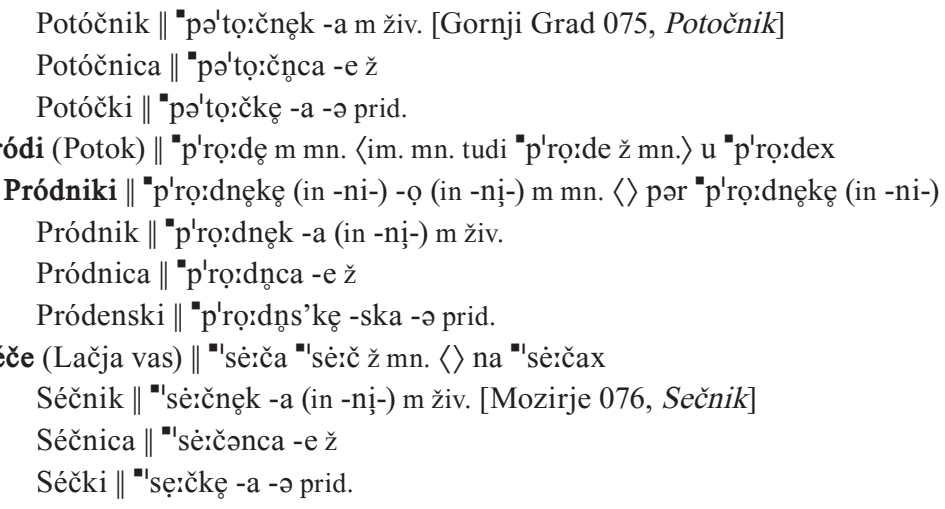

Skónčnjaki Skónčneki (Bočna) || "s'kọ:nčnẹkę -u m mn. 〈〉 pər "s'kọ:nčnẹkẹ

Skónčnjak Skónčnek || 's'kọ:nčnek -a (in -nẹ-) m živ. (priimek Skónčnik)

Skónčnica || "s'kọ:nčənca -e ž

Skónčki ||"s'kọ:nčkę -a -ə prid.

Slopí (Rovt pod Menino) || "słə'pi "słə'pi ž mn. 〈〉 na "słə'pe:x

Slopník || "słəp'nịk -a m živ. (priimek Slápnik)

Slopníca || "słəp'nịca -'nice ž

Slopníkov || "słəp'nịkọ -va -ə prid.

Sprebíja (Šmartno ob Dreti) \|" spra'bija -a ž $\rangle$ na "spra'bijə

in Sprebítniki || "spra'bit'nȩkę (in -ni-) -ọ (in -nị-) m mn. 〈〉 pər "spra'bit’nȩkę (in -ni-)

Sprebítnik || "spra'bit'nȩk -a (in -nị-) m živ. [Mozirje 076, Sprebitnik]

Sprebítnica || "spra'bịtnoca -e ž

Sprebítnikov || "spra'bit'nękọ -va -ə (in -nị-) prid.

tudi Sprebítkov || "spra'bit'ko -va -ə prid. ${ }^{14}$

Srnják (Potok) \|" "sər'n’åkk -a m \langle\rangle na "sər'n’åkə

in Srnjákerji || "sər'n’å:kẹjə -ọ m mn. 〈〉 pər "sər'n’åkẹrjə

Srnjáker || "sər'n’å:ker -kẹrja m živ.

Srnjákerica || "sər'n’å:kerca -kẹrce ž

Srnjákerjev || "sər'n’åkerjọ -va -ə prid.

Šetínec (Lačja vas) || "ša'tịnc -a m \langle\rangle u "ša'tịncə

Šetínščak $\sim$ Šetínšek ||"ša'tinšak -a m živ.

Šetínščica ||"ša'tinšca -e ž

Šetínski || "ša'tin'skę -ska -ə prid.

Temník (Rovt pod Menino) \|" "təm'nịk -a m 〈〉 u "təm'nịkə

Tomníščak $\sim$ Tomníšek \| "təm'nišak -a m živ. [Mozirje 076, Tomnišek] (priimek Tomínšek $)^{15}$

${ }^{14}$ Prim. Weiss 1990, 206: »za sprav'bit'kave [..] 'nivę«.

${ }^{15}$ O tem Janez Keber 1982, 231 v prispevku o izvoru priimkov na -šek: »[..] priimek Tominšek ni iz kr.[ajevnega] imena Tolmin, ampak iz mikrotoponima Temine, kar dokazuje zgodovinski material, a tudi današnja značilna razprostranjenost itd.« V opombi k temu pa: »Prim. por.[očno] knjigo Gornji grad: 1771 Georgius Thominshegk, 1774 Josephus teminscheg in isti 1775 in 1779 Temnischeck itd.« Sámo ledinsko ime je zapisano že v urbarju iz leta 1426: »Michel in temnikch« (Orožen 1876, 260). 
Tomníščica || "təm'nišca -e ž

Temníški || "təm'niškę -a -ə prid.

Tráte (Potok) || "t'rå:te "t'rå:t ž mn. 〈〉 na "t'rå:tex

Trátnik || "t'rå:tnęk -a (in -nị-) m živ. (priimek Trátnik)

Trátnica \|" t'rå:tñca -e ž

Trátenski || 't'rå:tnos'kę -a -ə prid.

Viclôvec (Rovt pod Menino) || "vẹc'lọ̣c -a m 〈〉 u ("s'pó:d'nęmə, "z'gỏ:rnęmə) "vęc'lọ:cə

Viclôvnik || "vęc'lọ:nęk -1ka m živ. [Gornji Grad 075, Vrclovnik]

Viclôvnica \|| "vẹc'lọ:nca -e ž

Viclôvški || "vęc'lọ:škę -a -ə prid.

Viníše (Lačja vas) || "vę'niša "vę'niš ž mn. 〈〉 na ("s'pỏ:d'nęx, "z'gó:rnęx) "vę'nišax

Viníšnjak Viníšnek \| "vẹ'nišnek -a m živ. [Mozirje 076, Venišnik] (priimek Veníšnik)

Viníšnica || "vę'nišənca -e ž

Viníški \|"vè'niške -a -ə prid.

Vóloga (Rovt pod Menino) \|" vəłaga -e ž $\rangle$ u"vəłage

Vóložnik ||"vəłažnęk -a (in -nị-) m živ. [Mozirje 076, Volažnik]

Vóložnica ||"vəłažənca -e ž (tudi vodno ime [Mozirje 076: Voložnica])

vóloški || 'vəłaškę -a -ə prid.

Vrtáče (Spodnje Kraše) || "vər'tå:ča "vər'tå:č ž mn. 〈〉 na "vər'tå:čax ${ }^{16}$

Vrtáčnik || "vər'tå:čnȩk -a (in -nị-) m živ. [Mozirje 076: Vrtačnik] (priimek Vrtáčnik)

Vrtáčnica || "vər'tå:čənca -e ž

Vrtáčki || "vər'tå:čkę -a -ə prid.

Vrtáčniki (Rovt pod Menino) || "vər'tå:čnękę (in -ni-) -ọ (in -nị-) m mn. 〈〉 pər "vər'tå:čnękę (in -ni-)

Vrtáčnik || "vər'tå:čnȩk -a (in -nị-) m živ.

Vrtáčnica || "vər'tå:čənca -e ž

Vrtáčki || "vər'tå:čkę -a -ə prid.

Zakót (Bočna) \|" "za'kọ:t -a m \langle\rangle u "za'kọstə

Zakótnik || "za'kọ:t'nȩk -a (in -nị-) m živ.

Zakótnica \|" za'kọ:tnoca -e ž

Zakóčki || "za'kọ:čkę -a -ə prid.

Závršniki (Čreta pri Kokarjah) ||"'zå:vəršnękę (in -ni-) -ọ (in -nị-) m mn. 〈〉 pər "zå:vəršnękę (in -ni-)

Závršnik ||"zåivəršnȩk -a (in -nị-) m živ. [Mozirje 076, Završnik]

Závršnica ||"zå:vəršənca -e ž

Závrški ||"'zå:vərške -a -ə prid. [Mozirje 076, Završki vrh (828 m)]

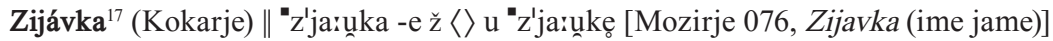

${ }^{16}$ Gole Vrtače je ime področja južno od Šmartna ob Dreti in Spodnjih Kraš (Mozirje 076).

${ }^{17}$ Badjura 1953, 295, 296, 297 ima - tako kot pred njim že Pleteršnik v slovensko-nemškem slovarju iz leta 1895 - zijavka, medtem ko ima Slovenski pravopis 2001/2003 zijávka (v geslu zijávec, slabšalno za 'radovedna opazovalka') in čisto drugo obliko v geslu Potóčka zijálka (zadnje bi se glede na to, da posebni izgovor ni zapisan, torej v knjižnem jeziku moralo izgovarjati z [1k]). 
in Zijávčnjaki Zijávčneki || "z'ja:ưčnẹkę -nekọ (in -nẹ-) m mn. 〈〉 pər "z'ja:ưčnẹkẹ Zijávčnjak Zijávčnek ||"z'ja:ǔčnek -a (in -nẹ-) m živ.

Zijávčnica || "z'ja:ưčənca -e ž

Zijávčki \||"z'ja:ưčkę -a -ə prid.

Žífrje (Kokarje) \|" "žifərjə -a s \langle\rangle u "žịfərjə [Mozirje 076, Žiferje (ledinsko ime)] Žífrnjak Žífrnek || '̌̌ịfərnek -a m živ. [Mozirje 076, Žifernik]

Žífrnica \| '̌̌i̧frənca -e ž

Žífrski ||"Žịfərs'kę -ska -ə prid.

\section{Navedenke}

AS 1996 = Atlas Slovenije, ur. Vili Kos, Ljubljana, Mladinska knjiga - Geodetski zavod Slovenije, ${ }^{3} 1996$.

Badjura 1953 = Rudolf Badjura, Ljudska geografija: terensko izrazoslovje, Ljubljana, DZS, 1953.

Bajec 1950 = Anton Bajec, Besedotvorje slovenskega jezika 1: Izpeljava samostalnikov, Ljubljana,SAZU, 1950 (Dela razreda za filološke in literarne vede 1).

Blaznik 1986 = Pavle Blaznik, Historična topografija slovenske Štajerske in jugoslovanskega dela Koroške do leta 1500 1-2: A-M, N-Ž, Maribor, Obzorja, 1986.

Gornji Grad 075 = Državna topografska karta Republike Slovenije 1 : 25.000: Gornji Grad (075), Ljubljana, Geodetska uprava Republike Slovenije, 1998.

Keber 1982 = Janez Keber, O izvoru priimkov na -šek, Onomastica Jugoslavica 9 (1982), str. 229-236.

Keber 2002 = Janez Keber, Rojstna imena, hišna imena, vzdevki, psevdonimi $\mathrm{v}$ Sloveniji, Jezikoslovni zapiski 8 (2002), št. 2, str. 47-69.

Keber 2002a = Janez Keber, Slovarček imenoslovnih in drugih jezikoslovnih izrazov, Jezikoslovni zapiski 8 (2002), št. 2, str. 141-148.

Mišič 1938 = Franc Mišič, O ledinskih in hišnih imenih okoli Solčave, Časopis za zgodovino in narodopisje 33 (1938), str. 191-201.

Mišič 1940 = Franc Mišič, Ledinska in hišna imena okoli Luč, Časopis za zgodovino in narodopisje 35 (1940), str. 40-49.

Mozirje 076 = Državna topografska karta Republike Slovenije 1 : 25.000: Mozirje (076), Ljubljana, Geodetska uprava Republike Slovenije, 1998.

Mrdavšič 1988 = Janez Mrdavšič, Krajevna in domača imena v Črni na Koroškem in njeni širši okolici, Ravne na Koroškem: Koroška osrednja knjižnica »Dr. Franc Sušnik« - Kulturna skupnost, 1988.

Mrdavšič 2001 = Janez Mrdavšič, Krajevna in domača imena v Mežiški dolini, Ravne na Koroškem: ČZP Voranc, 2001.

Orožen 1876 = Ignac Orožen, Das Benediktiner-Stift Oberburg, Marburg, 1876 (Das Bisthum und die Diözese Lavant I/1).

Ramovš 1952 = Fran Ramovš, Morfologija slovenskega jezika: skripta, prirejena po predavanjih prof. dr. Fr. Ramovša v l. 1947/68, 48/49, Ljubljana: DZS (za Univerzitetno študijsko komisijo), 1952. 
Škofic 2001 = Jožica Škofic, Hišna imena v Kropi, Simpozij Slovenska lastnoimenskost: zbornik s simpozija '99 v Pišecah, ur. Jože Toporišič, Pišece, Komisija Maks Pleteršnik - Novo mesto, Tiskarna Novo mesto, Dolenjska založba, str. 21-40.

Štiftar 1873 = France Štiftar, O vlastnih imenih kmetij i posestnikov v Solčavi, Vestnik Zore 1873, str. 168-170.

Trdina 1987 = Janez Trdina, Podobe prednikov: zapiski Janeza Trdine iz obdobja 1870-1879, ur. Snežana Štabi - Igor Kramberger, Ljubljana, Univerzitetna konferenca ZSMS, 1987 (Knjižna zbirka Krt 30-32).

Vider 1982 = Valent Vider, Zapiski o Solčavi in njeni okolici: prispevki kzgodovinskemu in etnografskemu gradivu, Solčava, Turistično društvo, 1982.

Weiss 1990 = Peter Weiss, Govori Zadrečke doline med Gornjim Gradom in Nazarjami: glasoslovje, oblikoslovje in skladnja - magistrsko delo, Ljubljana, 1990 (tipkopis).

Weiss 1998 = Peter Weiss, Slovar govorov Zadrečke doline med Gornjim Gradom in Nazarjami: poskusni zvezek (A-H), Ljubljana, Založba ZRC, 1998 (Slovarji).

Weiss 2001 = Peter Weiss, Folološki opis govora kraja Spodnje Kraše (SLA 314), Jezikoslovni zapiski 7 (2001), št. 1-2, str. 321-347.

Weiss 2003 = Peter Weiss, Načini ogovarjanja in govorjenja o odsotni osebi v govorih spodnje Zadrečke doline, v: Glasoslovje, besedoslovje in besedotvorje v delih Jakoba Riglerja, ur. Zinka Zorko - Mihaela Koletnik, Maribor: Slavistično društvo, 2003 (Zora 25), str. 199-215.

Weiss 2004 = Peter Weiss, Izhodišča za slovar imen v govorih spodnje Zadrečke doline, Besedoslovne lastnosti slovenskega jezika: slovenska zemljepisna imena, ur. Marko Jesenšek, Ljubljana, Slavistično društvo Slovenije - Pišece, Društvo Pleteršnikova domačija, 2004, str. 147-153.

\section{Oeconyms Formed from Choronyms in the Lower Dreta Valley} Summary

In the Upper Savinja Valley, the oldest oeconyms were formed from names that were originally microtoponyms; for example, Potok 'creek' and the prepositional phrase v Potoku. Adjectives added to these house names usually have the suffix -ski etc. (e.g., Potočki), whereas the suffix -ov etc. from the owner's name (e.g., Hosta, v Hosti-Hostnikov) is less frequently used. However, the latter is the only suffix used with most of the more recent house names (e.g., Tinčki, pri Tinčki - Tinčkov). With both types of oeconyms, the adjectival form in -ov etc. refers to the owner (e.g., Potočnik, Tinček - Potočnikov, Tinčkov). The type Skončnjaki, pri Skončnjaki - skončki is rare; the original microtoponym is no longer present (or has never been), but the adjective behaves as though it were (or had been). This article presents today's distribution of oeconyms formed from names that were originally choronyms in the lower Dreta Valley (where the Upper Savinja dialect is 
$\rightarrow \quad$ spoken between Gornji Grad and Nazarje), including derivatives and prepositional phrases. In addition, attention is called to their diminishing use.

Peter Weiss

Inštitut za slovenski jezik Frana Ramovša ZRC SAZU Novi trg 2, 1000 Ljubljana 